\title{
Towards a smart, inclusive and sustainable development. Investment in human capital and innovation. An empirical analysis
}

\author{
Emilia HERMAN \\ University of Medicine, Pharmacy, Sciences and Technology of Tirgu-Mures, Romania \\ emilia.herman@ea.upm.ro
}

\author{
Marta-Christina SUCIU \\ The Bucharest University of Economic Studies, Faculty of Theoretical and Applied Economics, \\ Department of Economics \& Economic Policies, Bucharest, Romania \\ christina.suciu@economie.ase.ro
}

\begin{abstract}
The importance of a smart, inclusive and sustainable development as well as their main determinants had benefit in the last decades of an emergent attention both in the current evolution of the mix set of socio and economic policies as well as in the theoretical and empirical research development. The paper focuses on the role of investments in human capital and innovation, two closely interrelated variables, for a smart, inclusive and sustainable development, within the European Union countries. Our main research results show that, at the EU level, there are significant differences between less inclusive and sustainable developed countries and, correspondingly, between more inclusive and sustainable developed countries in terms of investments in human capital (expressed by the Global Human Capital Index and tertiary educational attainment), on one hand, and the national innovation systems performances (as illustrated by the Summary Innovation Index and R\&D intensity), on the other hand. Moreover, the correlation and regression analysis results suggest that existing gaps between inclusive and sustainable development, manifested at the EU level, can be explained by the level of human capital optimization and innovation performances. Therefore, more attention have to be paid to take some specific actions, especially in the less inclusive and sustainable developed countries (such as Romania, Greece, Spain, and Portugal, called also emergent countries) in order to improve innovation performance and the leverage of the human capital for the benefit of both individuals' themselves and of the whole economy for increasing the inclusiveness and sustainability of development.
\end{abstract}

Keywords: investments in human capital, innovation, inclusive and sustainable development, EU.

\section{Introduction}

Inclusive, smart and sustainable development is one of the most recent research areas in socio-economics sciences, as well as a key-objective for the international and national strategies. According to Gupta et al. (2015, p. 546), inclusive development refers to the "development that includes marginalized people, sectors and countries in social, political and economic processes for increased human wellbeing, social and environmental sustainability, and empowerment". Inclusive development is a multidimensional concept that has at least three dimensions that are interconnected to one another: social inclusion, political and environmental dimension (van Gent, 2017). Moreover, the World Economic Forum (WEF, 2018), in order to estimate an Inclusive Development Index for 103 economies had evaluated 
three pillars, considered to be very important for the inclusive development: growth and development; inclusion; equity and sustainability.

The importance of inclusiveness and sustainability for development has received growing attention in the current development policy. Thus, some of the $17^{\text {th }}$ Sustainable Development Goals (SDG) of the 2030 Agenda for Sustainable Development adopted by the member states of the United Nations (see UN, 2015) highlights the importance of inclusive development either directly or indirectly for the long-run smart, sustainable \& inclusive development. Furthermore, $4^{\text {th }}$ SDG - "Ensure inclusive and equitable quality education and promote lifelong learning opportunities for all" and 9thSDG- "Build resilient infrastructure, promote inclusive and sustainable industrialization and foster innovation" represent essential ways to perform inclusive and sustainable development. Also, at EU level, it is recognized, through the Europe 2020 Strategy (European Commission, 2010), that improving human capital and innovation can definitely contribute to a smart, sustainable and inclusive development.

Human capital is a complex concept which "consists of the knowledge, skills, and health that people accumulate over their lives, enabling them to realize their potential as productive members of society" (World Bank, 2019, p. 50). A large number of theoretical and empirical studies, which focus on human capital and innovation, as well as on the human capital - innovation relationship, have highlighted their significant influence on the economic growth and development, but less on inclusive development. Therefore, we consider that there is a need for further research considering the impact of investing in human capital and innovation on inclusive, smart and sustainable development.

The paper focuses on investments in human capital and innovation as main determinants of inclusive and sustainable development in the European Union countries. Although human capital includes at least education, skills, and health, the main focus of this paper is on the influence of human capital as "knowledge and skills people possess that enable them to create value in the global economic system" (World Economic Forum, 2017a, p.3), based on Global Human Capital Index.

\section{Brief literature review}

Investing in human capital, human capital and innovation are closely interrelated concepts, acting through multiple pathways as key factors for competitiveness, and development (World Economic Forum, 2017a, OECD 2012; Diebolt and Hippe, 2019). The positive expected effects of human capital investments (usually measured as education capital) on economic growth and development through increasing labour productivity is highlighted in a large body of literature (Lucas, 1988; Mankiw et al., 1992; Krueger and Lindahl, 2001; De la Fuente and Doménech, 2006; Pelinescu, 2017). Moreover, investments in human capital may indirectly influence economic \& social growth and development, through innovation, but also through generating, developing and implementing new technologies (Romer, 1990; Aghion and Howitt, 1998; Acemoglu and Autor, 2012; WEF, 2017a; EU, 2018a; WB, 2019). According to the Global Competitiveness Report (WEF, 2017b), education (primary education, higher education and training), innovation and health are essential factors of national competitiveness and economic development. 
Becker (1964), recognized as one of the pioneers a founder of human capital theory, emphasizes that human capital investments highly contribute to the increase of the workers' productivity and implicitly to a relatively stable increase of workers' income.

Mincer (1958) explains inequality in personal incomes due to different level of education. Moreover, the difference in income between countries can be mainly explained by the difference in knowledge investment (R\&D investment rates), as Klenow and Rodriguez-Claire (2004) state. Educational attainment and skills have important positive economic and social outcomes both for individuals and for an inclusive society as a whole (Suciu, 2001; Riddell and Song, 2011; WEF, 2017a; OECD, 2018). Thus, a high level of educational attainment is associated with a high employment rate and a low unemployment rate (EU, 2018; Herman, 2012, 2016; Barbulescu, 2012), and with high labour productivity (Herman, 2012; WEF, 2017b; OECD, 2018). Other authors had investigated also the situation of labour force with low earnings and correspondingly with a high risk of poverty and risk of in-work poverty (Eurofound, 2017; Herman, 2014; Lane and Conlon, 2016),

Hanushek and Woessmann $(2011,2015,2016)$ had focus mostly on the importance of cognitive skills compared to the length of education (estimated based on the average years of schooling or educational attainment levels), as a specific indicator for human capital investments, highlighting that the quality of education matters more for a smart, sustainable \& inclusive development than the quantity of education. Furthermore, the World Development Report (World Bank, 2019) highlights that the knowledge students acquire while in school influences economic growth and development more than the years of education completed. According to EU Report (European Union, 2018b, p.3) "better education and the upgrading of the skills of the European labour force are key to reaping the benefits and minimizing the risks of transformations in production".

An important way through which investments in human capital can boost economic growth and development is by improving the capacity to absorb and adapt new technology (World Bank, 2018), the human capital being positively correlated with the level of adoption of advanced technologies (OECD, 2012; Szabo and Herman, 2014; World Bank, 2019) and national innovation capacity (EU, 2017). Moreover, empirical studies (Szabo and Herman, 2012; Kelley et al., 2016) highlighted that cross-countries differences in the level of economic development can be explained based on the main gaps in innovation performances. OECD (2012) shows that innovation capacity has to be built early in the development process, as this leads to the acquisition of learning capacities that will allow developing and emerging countries to catch up with the developed countries. Innovation has a pivotal role in all stages of development, as it is known that the types and role of innovation are different according to these stages.

Innovation can be seen as a prerequisite for creative \& innovation based economy \& society, highly contributing to the improving of people's quality of lives and correspondingly to the overall socio-economic development on the micro, mezzo and macro levels (Suciu et al., 2018). Technological and social innovation can play an important role for a smart, sustainable \& inclusive development (Osakwe and Moussa, 2017) depending also on the extent to which new innovations might generate better quality, highly skilled jobs, including the so-called "green jobs" that contribute also to the reduction of the environmental pollution, improving health, and finally conducting towards positive 
externalities long-run effects on competitiveness, quality of life \& living standards (Naude and Nagler, 2015).

\section{Main data and methodology}

In order to analyse human capital \& correspondingly human capital investments, we have used the Global Human Capital Index (GHCI) taking into account that this index "assesses the degree to which countries have optimized their human capital for the benefit of their economies and of individuals' themselves" (World Economic Forum, 2017a, p. 4) on a scale from 0 (worst) to 100 (best). GHCI includes four sub-indexes - capacity, deployment, development and know-how and 30 main indicators.

Additionally, we used the public expenditure on education (as \% of GDP) and tertiary educational attainment (as the percentage of the population aged 30-34 who have successfully completed tertiary studies) as proxies for human capital. Innovation performance in the EU countries is highlighted based on Summary Innovation Index (SII), which according to the EU report includes "four main types of indicators and ten innovation dimensions, capturing in total 27 different indicators" (EU, 2018a, p.7].

We used the Inclusive Development Index (IDI), a composite index which covers three inclusive development dimensions: growth and development, inclusion and equity, and sustainability (WEF, 2018) as a proxy for inclusive development. IDI scores are based on a scale from 1 (worst) to 7 (best). The Sustainable Development Goal (SDG) Index is used for assessing the sustainable development from the perspective of degree of achievement of Sustainable Development Goals of Agenda 2030 (UN, 2015). The SDG Index score shows a country's position between the worst (0) and the best or target (100) outcomes and can be interpreted as the percentage of achievement (Sachs et al., 2018). Based on the Inclusive Development Index score and the SDG Index, we had identified two groups of EU countries.

- In the first group, "More inclusive and sustainable developed countries group" (More ISD), we included twelve countries (Luxembourg, Denmark, Sweden, Netherlands, Ireland, Austria, Finland, Germany, Belgium, Czech Republic, France and Slovenia) whose IDI score and SDGI score were both above the EU-25 average (except for Luxemburg which is the EU leader in terms of IDI score, but below the EU-25 average as regards the SDGI score).

- The second group, "Less inclusive and sustainable developed countries group" (Less ISD), includes fourteen countries whose IDI score and SDGI score were both below the EU-25 average (except for the United Kingdom and Estonia which have SDGI score above the EU-25 average).

Our sample consists of 26 countries from EU, without Malta and Cyprus, the countries for which IDI scores are unavailable. We used the data for 2017 which have been collected by from the Eurostat database (2019), European Union (2018), World Economic Forum (2017a; 2018), and Sachs et al. (2018). The descriptive statistics (minimum, maximum, mean and standard deviation) of the variables included in the analysis for our sample is presented in Table 1. 
Table 1. Variables included in analysis. Descriptive statistics

\begin{tabular}{|l|c|c|c|c|c|}
\hline \multicolumn{1}{|c|}{ Variables } & N & Minimum & Maximum & Mean & Std. Deviation \\
\hline IDI & 26 & 3.7 & 6.07 & 4.922 & 0.569 \\
\hline GHCI & 26 & 64.68 & 77.07 & 70.284 & 3.338 \\
\hline SII & 26 & 0.157 & 0.71 & 0.454 & 0.159 \\
\hline GERD1 & 26 & 0.5 & 3.33 & 1.647 & 0.863 \\
\hline $\begin{array}{l}\text { Public expenditure } \\
\text { on education }\end{array}$ & 26 & 3.1 & 7 & 5.035 & 0.973 \\
\hline Tertiary education & 26 & 26.3 & 58 & 41.850 & 8.739 \\
\hline SDGI & 26 & 70.6 & 85 & 77.338 & 3.928 \\
\hline
\end{tabular}

Note: $1 \%$ of GDP; ${ }^{2}$ Tertiary educational attainment (percentage of the population aged 30-34 who have successfully completed tertiary studies).

Source: Authors' own research based on Eurostat database (2019), EU (2018), WEF (2017a, 2018)

In order to examine whether there are significant differences between the two groups of countries (More ISD group vs. Less ISD group) in terms of the indicators related to human capital and innovation, the independent samples t-test was applied. We have applied the Pearson correlation coefficient (r) to study the intensity of the relationship between the analysed indicators, at the level of this sample. In order to highlight the role of human capital and innovation in inclusive and sustainable development we applied the regression technique. For data processing and analysis, the SPSS software package was used.

\section{Main results and discussions}

Data from Figure 1 illustrate that GHCI score varies markedly across the EU countries (26 countries, without Cyprus and Malta), from 77.07\% (Finland) to 64.68\% (Greece). These GHCI scores highlight that all the EU countries should do "more to nurture and fully develop their human capital" (WEF, 2017a, p. 4). The Nordic EU countries recorded the highest GHCI value (over 75\%), Finland (with a score of 77.07\%) being the EU leader, ranking $2^{\text {nd }}$ (after Norway) out of 130 countries. In the last four positions in the EU, along with Romania, we found the Southern countries (Greece, Spain, and Portugal), with a score between $66 \%$ and $64.68 \%$, fact which reflects the largest gaps in human capital optimization.

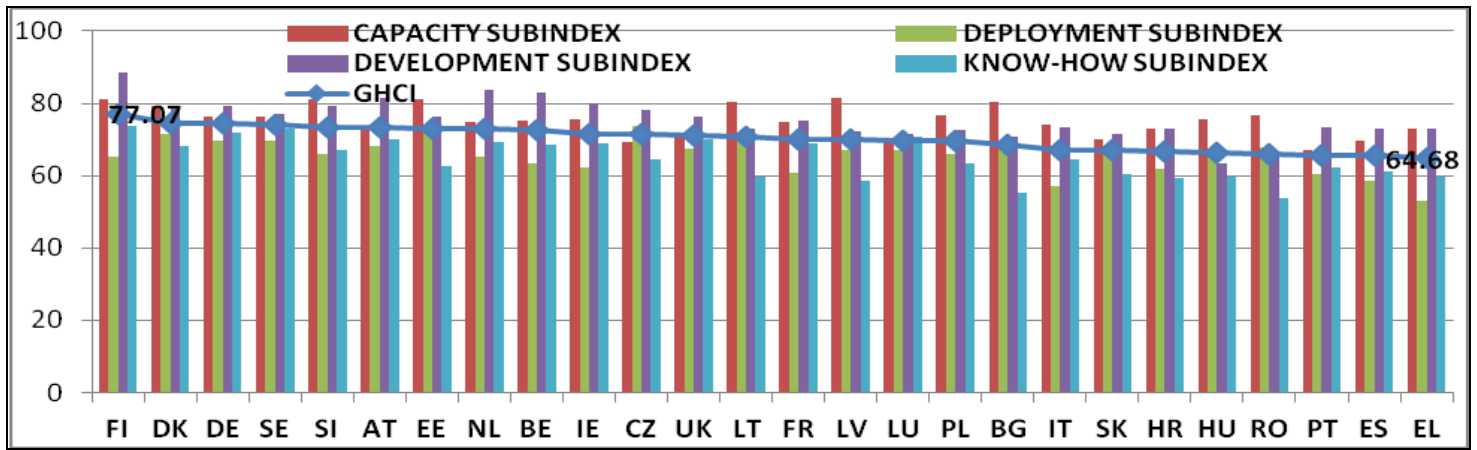

Figure 1. Global Human Capital Index (GHCI) and sub-indexes GHCI, in 2017, in the EU-25 countries

Source: Designed by authors based on data provided by WEF (2017a) 
Results of the independent samples t-test (Table 2) show significant differences between more inclusive \& sustainable developed countries group $(N=12)$ and less inclusive \& sustainable developed countries $(N=14)$, in terms of human capital (GHCI).

On average, more ISD countries group have a much higher GHCI score than less ISD countries group (score of $72.875 \%$ and $68.063 \%$ ).

Table 2. Results of independent samples t-test: More inclusive and sustainable developed (ISD) countries group versus less inclusive and sustainable developed countries group

\begin{tabular}{|c|c|c|c|c|c|c|}
\hline \multirow[b]{2}{*}{ Variables } & \multicolumn{2}{|c|}{ Mean } & \multicolumn{2}{|c|}{ Levene's Test ${ }^{1}$} & \multicolumn{2}{|c|}{ t-test ${ }^{2}$} \\
\hline & $\begin{array}{c}\text { Less ISD group } \\
(\mathrm{N}=14)\end{array}$ & $\begin{array}{c}\text { More ISD group } \\
(\mathrm{N}=12)\end{array}$ & $\mathbf{F}$ & Sig. & $\mathbf{t}$ & Sig. ${ }^{3}$ \\
\hline GHCI & 68.063 & 72.875 & 1.349 & 0.257 & -5.364 & 0.000 \\
\hline SII & 0.338 & 0.590 & 0.345 & 0.562 & -6.766 & 0.000 \\
\hline GERD & 1.051 & 2.343 & $\begin{array}{c}11.26 \\
5\end{array}$ & 0.003 & -5.733 & 0.000 \\
\hline $\begin{array}{l}\text { Public expenditure } \\
\text { on education }\end{array}$ & 4.736 & 5.383 & 0.359 & 0.555 & -1.730 & 0.098 \\
\hline Tertiary education ${ }^{2}$ & 38.836 & 45.367 & 4.177 & 0.052 & -2.074 & 0.050 \\
\hline
\end{tabular}

Note: ${ }^{1}$ Levene's test for equality of variances delivered a significance value higher than 0.05 for all the variables (except GERD), for which the "equal variances assumed" option was used; $\mathrm{df}=24$; ${ }^{2}$-test for equality of means; ${ }^{32}$ tailed.

Source: Authors' own research

There are significant differences between the two groups in terms of the GHCI subindex (Figure 1 and Figure 2). More accentuate differences are recorded in the case of the development sub-index of GHCI (79.64\% against $72.02 \%$ ) and the know-how sub-index (69.55\% against $60.65 \%)$. In the case of less ISD countries group, lower know-how, but high capacity "suggests ample opportunities to focus on expanding know-how through different mechanisms such as deepening participation in global value chains" (World Economic Forum, 2017a).

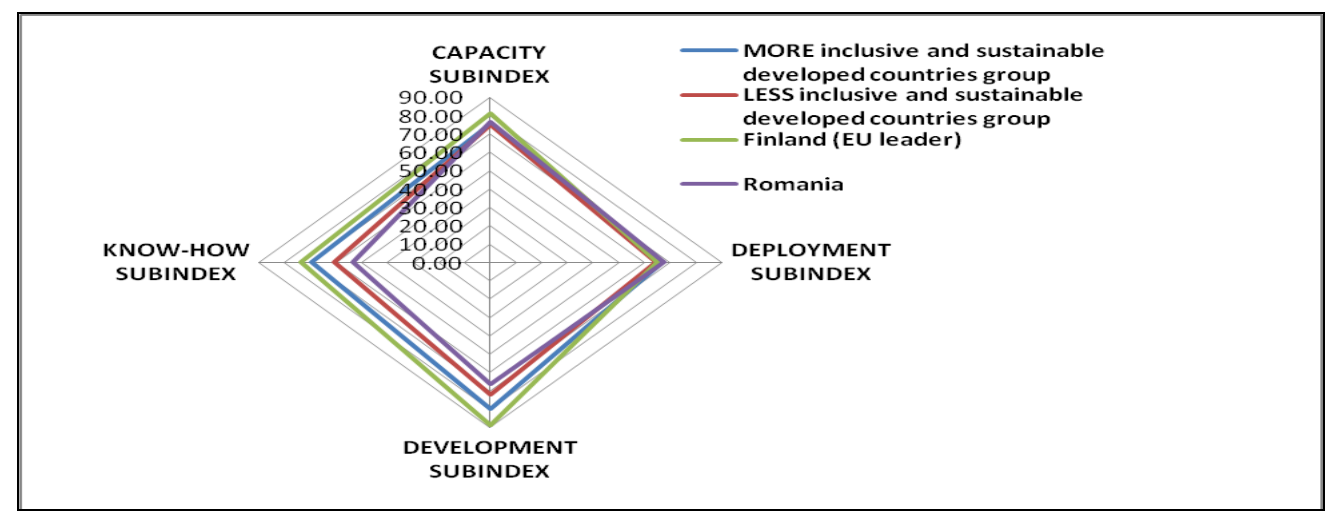

Figure 2. Human capital (GHCI) dimensions in the EU context

Source: Designed by the authors based on data provided by WEF (2017a)

Romania, which belongs to the group of less inclusive and sustainable developed, having an overall GHCI score of $66.12 \%$, is ranked $42^{\text {nd }}$ globally out of 130 countries and $23^{\text {th }}$ out of $26 \mathrm{EU}$ countries. This score points out that Romania is currently leveraging only 
a bit over half of its human capital. Comparing the four dimensions of GHCI (Figure 2), it can be noticed that, in the case of Romania, the capacity sub-index (the existing stock of education across generations) has the highest value $\left(76.77 \%\right.$, being ranked $24^{\text {th }}$ out of 130 countries and $8^{\text {th }}$ out of 26 European Union countries).

These are followed by the deployment sub-index (active participation in the workforce across generations- 67.64\%) and the development sub-index (current efforts to educate, skill and upskill the student body and the working age population $-66.39 \%$ ). The know-how sub-index has the lowest value $\left(53.66 \%\right.$, ranked $54^{\text {th }}$ out of 130 countries and $26^{\text {th }}$ out of $26 \mathrm{EU}$ countries). This fact reflects a low "potential for enacting a virtuous cycle of opportunities for gaining new skills in the workplace and motivating investment in the development of higher skilled talent among private and public actors, as well as among individuals themselves" (WEF, 2017a, p.33).

The results of the correlation analysis regarding the relationship between the score of the Inclusive Development Index and correspondingly the score of Global Human Capital Index emphasize that there is a strong positive correlation at the EU level $(\mathrm{r}=+0.742$, $\mathrm{p}<0.01$, Figure 3 and Table 3 ).

Table 3. Multiple correlation matrix

\begin{tabular}{|c|c|c|c|c|c|c|}
\hline Variables & IDI & GHCI & SII & GERD ${ }^{1}$ & $\begin{array}{c}\text { Public expenditure on } \\
\text { education }\end{array}$ & $\begin{array}{c}\text { Tertiary } \\
\text { education }\end{array}$ \\
\hline IDI & 1.000 & $0.742 *$ & $0.781^{*}$ & $0.604^{*}$ & $0.405^{* *}$ & $0.530^{*}$ \\
\hline GHCI & & 1.000 & $0.736^{*}$ & $0.725^{*}$ & $0.580^{*}$ & $0.523^{*}$ \\
\hline SII & & & 1.000 & $0.821^{*}$ & $0.464^{* *}$ & $0.564^{*}$ \\
\hline GERD & & & & 1.000 & $0.535^{*}$ & 0.237 \\
\hline $\begin{array}{l}\text { Public expenditure } \\
\text { on education }\end{array}$ & & & & & 1.000 & $0.490^{* *}$ \\
\hline Tertiary education & & & & & & 1.000 \\
\hline
\end{tabular}

Note: *Correlation is significant at the 0.01 level (2-tailed); **at the 0.05 level (2-tailed).

Source: Authors' own research based on Eurostat database (2018), EU (2018) and WEF (2017a, 2018)

Thus, in the countries where human capital is higher, the level of inclusive and sustainable development is higher and vice versa. The results of the simple regression analysis $\left[R^{2}=0.551 ; F(1,24)=29.472\right.$; sig $=0.000$; regression coefficient $\left.(\beta)=+0.742\right]$ reflect the positive influence of the human capital on inclusive development, at EU level. Therefore, the gaps between the EU member states, in terms of inclusive and sustainable development, can be explained by the differences recorded in terms of human capital.

As regards the innovation performance (proxy: SII), heterogeneity can be observed at EU level, as significant differences between the two groups of countries have been identified (0.59 against 0.34 , Table 2 ).

In the less inclusive and sustainable developed countries group, SII score ranges from 0.157 (in Romania) to 0.613 , in UK (Figure 4) and all the countries (except the UK) that belong to this group are "moderate innovators" and "modest innovators". "Innovation leaders" and "strong innovators" belong to more inclusive and sustainable developed countries group (except the Czech Republic). In the case of the UK, there is a higher quality of its innovation systems than IDI, fact that can be explained by the existence of welldeveloped capabilities for exploiting knowledge (Fagerberg and Srholec, 2008). A higher 
level of inclusiveness of development than innovation performance achieved by Czech Republic, a "moderate innovator", is explained based on the "highly distributive effects of its welfare system" (European Union, 2012).

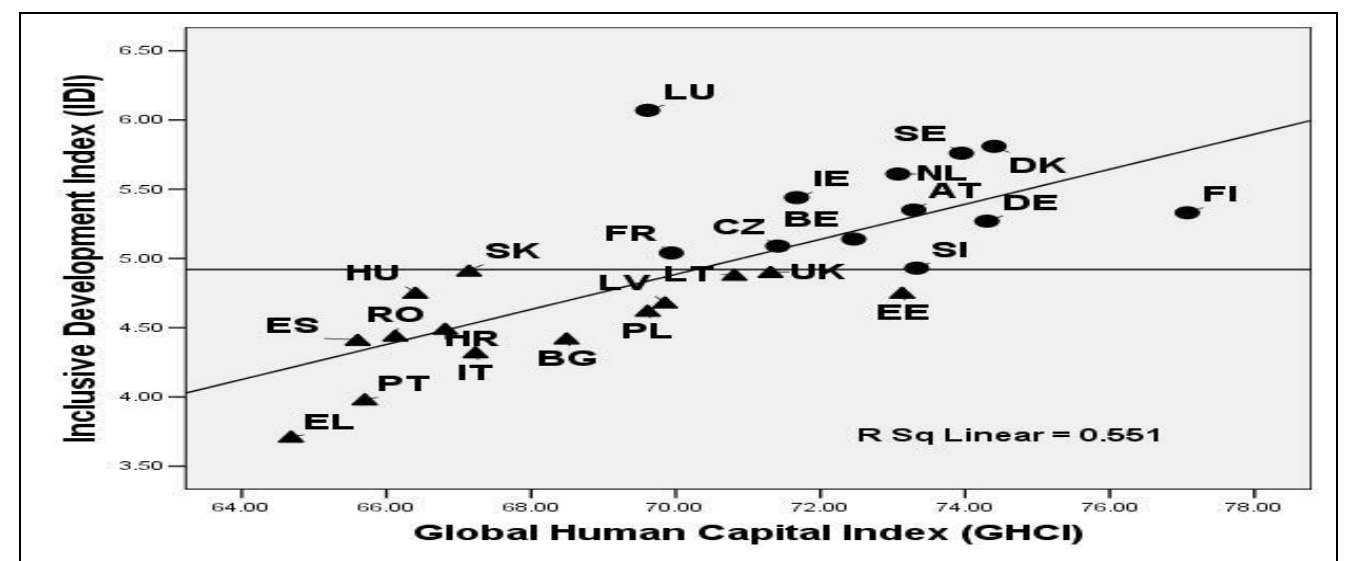

PICBE $\mid 799$

Figure 3. Human capital and inclusive development in the EU countries

Source: Authors' own research design based on WEF (2017a) and WEF (2018)

We found a positive correlation between SII and IDI $(r=+0.784, p<0.01$, Figure 4 and Table 3) and a significant positive influence of the SII on IDI $\left[R^{2}=0.609, F(1,24)\right.$ $=37.457$, sig $=0.000, \beta=+0.781]$. Thus, as the state has a high innovation performance, it will achieve more in terms of inclusive and sustainable development.

Moreover, SII is positively correlated with GHCI $(\mathrm{r}=+0.736, \mathrm{p}<0.01$, Table 3$)$ and Tertiary educational attainment- percentage of the population aged 30-34 who have successfully completed tertiary studies $(r=+0.564, p<0.01$, Table 3$)$. Thus, human capital (proxy: GHCI), high educational attainment and quality and capacity of the educational sector at all levels can boost innovative capacity of the country.

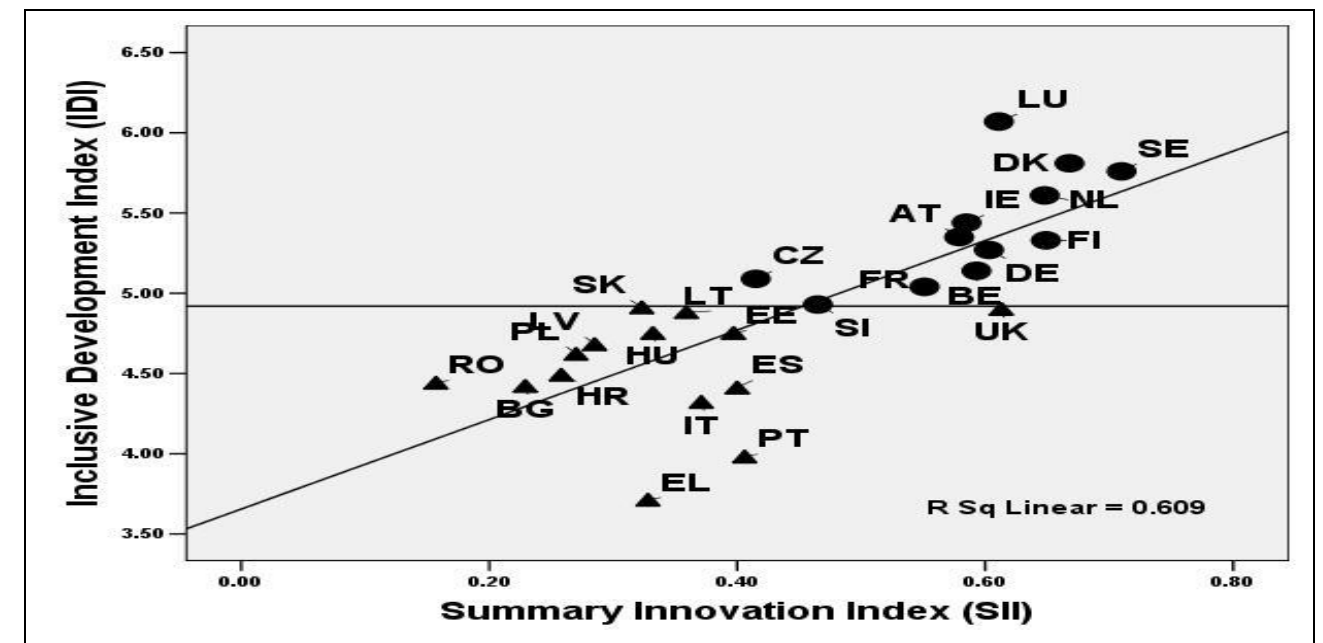

Figure 4. Innovation performance and inclusive development in the EU countries Source: Authors' own research design based on WEF (2018) and EU (2018)

If we compare the $R \& D$ intensity (GERD as \% of GDP) of the EU countries relative to level of inclusiveness and sustainability of development (Table 2), the results of 
independent samples t-test show significant differences between the two groups of countries $[\mathrm{t}(24)=-5.733 ; \mathrm{p}=0.000]$. On average, More ISD group has a much higher $R \& D$ intensity than Less ISD group (2.343\% as compared to $1.051 \%$ ).

Also, the level of tertiary educational attainment among more ISD group is higher than Less ISD group (45.367\% against 38.836\%), significant differences has been identified $[\mathrm{t}(24)=-2.074 ; \mathrm{p}=0.000]$.

At the EU level, the R\&D intensity is significantly and positively correlated both with SII $(r=+0.821, p<0.01)$ and IDI $(r=+0.604, p<0.01)$.

Thus, a greater allocation of funds in GDP for the R\&D activities generates a high innovation performance and inclusive and sustainable development, proving that $R \& D$ remains vitally important for economy.

A moderate positive link $(r=+0.464, p<0.01)$ has been identified between public expenditure on education (as \% of GDP) and SII (Table 3), emphasizing the fact that among countries where allocation of public funds for education is higher, innovation performance is high as well, and vice versa. Moreover, taking into account the results of the independent samples t-test (Table 2) which show insignificant differences between two groups of countries in terms of public expenditure on education [5.383\% as compared to $4.736 \%$; $\mathrm{t}(24)=-1.730 ; \mathrm{p}=0.098]$, it is highlighted that both the level of public expenditure on education and the effectiveness of this expenditure on education matter for development. As it is stated in the OECD Report (OECD, 2012), the countries which are confronted with limited budgets for education (especially less inclusive and sustainable developed countries group) face a real challenge when it comes to finding the right balance between the training of high-skill specialists (which imply high cost, but are essential for improving innovation) and training at the primary and secondary levels, "which, if absent, reduces absorptive capacities of the economy and the development of grassroots businesses" (OECD, 2012, p. 18). Furthermore, the same report, underlines that in order to increase inclusiveness of development the investment in human capital should be accompanied by providing the new and better employment opportunities.

\section{Conclusion and main implications}

This study explores the nexus of human capital, innovation and smart, inclusive \& sustainable development, focusing on the impact of human capital and innovation on the inclusive and sustainable development in the EU countries.

The results of independent samples t-test show that, at EU level, there are significant differences between less inclusive and sustainable developed countries group (14 countries) and more inclusive and sustainable developed countries group (12 countries) in terms of human capital (expressed by GHCI and tertiary educational attainment) and the national innovation performance (expressed by SII and R\&D intensity). Moreover, the correlation and regression analysis results suggest that the high level of inclusive and sustainable development in some EU countries can be mainly explained by a high level of human capital optimization and high innovation performance. Therefore, at the EU level, specific actions are required, especially in the less inclusive and sustainable developed countries group (such as Romania, Greece, Spain, and Portugal), to improve innovation performance and leveraging the human capital for the benefit of both individuals' themselves and the whole economy in order to increase inclusiveness and sustainability of 
development. Concerning the level of public expenditure on education, our results emphasize the need to achieve a greater allocation of funds in GDP for the expenditure on education as well as a higher effectiveness of these expenditures.

In the context of a higher speed of globalization and technological change, more attention needs to be paid to the re-orientation of educational policies and more efficient public spending in order to "ensure that the working age population is equipped with the right set of skills to reap the full benefits of structural change" (European Union, 2018b) and to face the challenges of the Fourth Industrial Revolution.

As a limitative aspect, we want to mention and express the fact that our study analyses only a quite limited number of indicators specific to human capital and innovation performance. Therefore, we consider that further research will have to be extended such as to allow a deeper analysis of the nexus of human capital investments, innovation and correspondingly to highlight more their potential impact for a smart, inclusive and long-run sustainable development.

\section{References}

Acemoglu, D., \& Autor. D. (2012). What does human capital do? A review of Golding and Katz's the race between education and technology. Journal of Economic Literature, $50(2), 426-463$.

Aghion, P., \& Howitt, P. (1998). Endogenous Growth Theorv. Cambridge, MA: MIT Press.

Barbulescu, A. (2012). Youth unemplovment in Romania and measures to combat it. Procedia Economics and Finance, 3, 1196-1201.

Becker, G. S. (1964). Human capital: a theoretical and empirical analysis with special reference to education. Chicago: University of Chicago Press.

Claude, D. \& Hippe, R. (2019). The long-run impact of human capital on innovation and economic development in the regions of Europe. Applied Economics, 51(5), 542-563, DOI: $10.1080 / 00036846.2018 .1495820$.

De La Fuente, Á., \& Domenéch, A. (2006). Human capital in growth regressions: how much difference does data quality make?, Journal of the European Economic Association, 2006, 4(1), 1-36.

Eurofound (2017). In-work poverty in the EU. Luxembourg: Publications Office of the European Union.

EU (2012). Employment and Social Developments in Europe 2011. Retrieved from http://ec.europa.eu/social/ main.jsp?catId=738\&langId=en\&pubId=6176

EU (2018a). European Innovation Scoreboard 2018. Luxembourg: Publications Office of the European Union.

EU (2018b). Employment and Social Developments in Europe. Luxembourg: Publications Office of the European Union.

Eurostat database (2019). Retrieved from https://ec.europa.eu/eurostat/data/database

Fagerberg, J. \& Srholec, M. (2008). National innovation systems, capabilities and economic development. Research Policy 37(9), 1417-1435.

Gupta, J., Pouw, N., \& Ros-Tonen, M. (2015). Towards an elaborated theory of inclusive development. European Journal of Development Research, 27(4), 541-559.

Hanushek, E. A., \& Woessmann. L. (2011). How much do educational outcomes matter in OECD countries? Economic Policy, 26 (67), 427-491.

Hanushek, E. A., \& Woessmann. L. (2012). Do better schools lead to more growth? Cognitive skills, economic outcomes, and causation. Journal of Economic Growth, 17(4), 267321.

Hanushek, E. A., \& Woessmann. L. (2016). Knowledge capital, growth, and the East Asian miracle. Science, 351 (6271), 344-345. 
Herman, E. (2012). Education's impact on the Romanian labour market in the European context. Procedia-Social and Behavioral Sciences, 46, 5563-5567.

Herman, E. (2014). Working poverty in the European Union and its main determinants: An empirical analysis. Enqineering Economics, 25(4), 427-436

Herman, E. (2016). Productive emplovment in Romania: a maior challenge to the integration into the European Union. Amfiteatru Economic, 18(42), 335-350.

Kelley, D. I., Singer, S., \& Herrington, M. (2016). The global entrepreneurship monitor. 20152016 Global Report. Retrieved from http://www.gemconsortium.org/report.

Klenow P.J., \& Rodriguez-Claire A. (2004) Externalities and Growth, Handbook of Economic Growth. Amsterdam: North Holland Press.

Krueger, A., \& Lindahl, M. (2001). Education for growth: Why and for whom? Journal of Economic Literature, 39(4), 1101-1136.

Lane, M. \& Conlon, G. (2016). The impact of literacy, numeracy and computer skills on earnings and employment outcomes. OECD Education Working Papers, No. 129, Paris: OECD Publishing.

Lucas, R. (1988). On the mechanics of economic development. Journal of Monetary Economics, 22 (1), 3-42.

Mankiw, N. G., Romer, D., \& Weil, D.N. (1992). Contribution to the Empirics of Economic Growth. The Quarterly Journal of Economics, 107(2), 407-437.

Mincer, J. (1958). Investment in human capital and personal income distribution. Journal of Political Economy, 66(4), 281-302.

Naude, W. \& Nagler, P. (2015). Industrialisation, innovation and inclusion. UNU-Merit: Working Paper no. 2015-043.

OECD (2012). Innovation for Development. A discussion of the issues and an overview of work of the OECD directorate for science, technology and industry. Retrieved from: https://www.oecd.org/innovation/inno/50586251.pdf

OECD (2018). Education at a Glance 2018.0ECD Indicators, Paris: OECD Publishing.

Osakwe P., \& Moussa, N. (2017). Innovation, diversification and inclusive development in Africa. UNCTAD. Retrieved from: https: //www.oecd.org/innovation/inno/50586251.pdf

Pelinescu, E. (2017). The human capital and development. The Romanian case studv. Working Papers of Institute for Economic Forecasting 170702, Institute for Economic Forecasting.

Riddell, W. C. \& Song, X. (2011). The impact of education on unemployment incidence and re-employment success: Evidence from the U.S. Labour Market. IZA Discussion Paper, No. 5572.

Romer, P. M. (1990). Endogenous Technological Change. Journal of Political Economy 98 (5, Part 2), 71-102.

Sachs, J., Schmidt-Traub, G., Kroll, C., Lafortune, G., \& Fuller, G. (2018). SDG Index and Dashboards Report 2018. New York: Bertelsmann Stiftung and Sustainable Development Solutions Network (SDSN).

Suciu, M.C. (2001). Investitia in educatie. Bucuresti: Editura Economica.

Suciu, M.C., Postma, E, Năsulea, C., \& Năsulea, D.F. (2018). Competitiveness \& innovation within the creative economy. BASIQ International Conference: New Trends in Sustainable Business and Consumption - 2018, p. 431-437. Retrieved from http://conference.ase.ro/pdf/BASIQ\%202018-\%20Volume.pdf

Szabo, Z. K., \& Herman, E. (2012). Innovative Entrepreneurship for Economic Development in EU. Procedia Economics and Finance, (3), 268-275.

Szabo, Z. K., \& Herman, E. (2014). Productive entrepreneurship in the EU and its barriers in transition economies: A cluster analysis. Acta Polytechnica Hungarica, 11(6), 73-94.

UN. (2015). Transforming our world: the 2030 Agenda for Sustainable Development. A/RES/70/1. Retrieved from: 
https://sustainabledevelopment.un.org/content/documents/21252030\%20Agenda \%20for\%20Sustainable\%20Development\%20web.pdf

van Gent, S. (2017). Beyond buzzwords: What is "Inclusive Development"? Synthesis report. Retrieved from https://includeplatform.net/wpcontent/uploads/2017/11/Final-Inclusive-Development-Report.pdf

WB-World Bank. (2018). Learning to realize education's promise. International Bank for Reconstruction and Development. Washington, DC: World Bank.

WB (2019). World Development Report 2019: The Changing Nature of Work. Washington, DC: World Bank.

WEF- World Economic Forum. (2017a). The Global Human Capital Report 2017. Geneva: World Economic Forum.

WEF (2017b). The Global Competitiveness Report 2017-2018. Geneva: World Economic Forum.

WEF (2018). The Inclusive Development Index 2018. Summary and Data Highlights. Geneva: World Economic Forum. 